\title{
THE EFFECT OF BREEDING REGION ON CERTAIN FERTILITY PARAMETERS OF SIMMENTAL COWS**
}

\author{
V. Pantelić ${ }^{*}$, Z. Skalicki ${ }^{2}$, M. M. Petrović ${ }^{1}$, S. Aleksić ${ }^{1}$, D. Ostojić- \\ Andrić $^{1}$, Ž. Novaković ${ }^{1}$ \\ ${ }^{1}$ Institute for Animal Husbandry, Belgrade-Zemun, 11080 Zemun \\ ${ }^{2}$ Faculty of Agriculture, Zemun \\ * Corresponding author:Vlada Pantelić, e-mail: vladapantelic.izs@gmail.com \\ **Original scientific paper - Originalni naučni rad
}

\begin{abstract}
Field of cattle reproduction is the most important production stage because it is in this stage that heads of cattle for renewal of herd are provided, also for production of milk and fattening, i.e. production of meat. In this study, the effect of breeding region on variability of age at calving and duration of service period in 3.641 first calving Simmental cows under control, reared on private farms on the territory of Republic of Serbia was investigated. In the analysis of collected data the method of Least Squares was used LSMLMW (Harvey 1990) according to following formula: $Y_{k m}=\mu+R_{k}+e_{k m}$. Regions had highly significant effect $(\mathrm{P}<0,01)$ on age at first calving and duration of service period. Through application of method of Least Squares average service period of 115,19 days and age at first calving of 795,53 days were established.
\end{abstract}

Key words: Simmental breed, fertility, regions.

\section{Introduction and literature review}

Success in improvement of fertility genetically is considerably limited by low heritability values, however, it doesn't mean that genes have no influence on this trait but that the value of additive genetic variation is low. Fertility of cows is more influenced by environment factors since majority of variations of reproductive traits is under their influence. In analysis of certain factors, their influence on cow fertility is of different level, and also complex effect is possible (Trifunović et al. 2004). 
Skalicki et al. (1991) investigated the effect of farm on reproductive traits. They concluded that the effect of farm was highly significant $(\mathrm{P}<0,01)$ on duration of service period and significant $(\mathrm{P}<0,05)$ on age at first conception and age at first calving.

In study of longevity and production of milk and milk fat of Simmental cows, Petrović (2000) established average age at first fertilization of 574,34 days. Cows calved for the first time at the age of 28,56 months. Duration of service period in average was 130,63 days.

In his research relating to genetic analysis of milk yield and reproduction traits of Simmental cows, Đurđević (2001) established average values for age of heads of cattle at first fertilization of 546,66 days, and first calving of 831,94 days. Service period between first calving and second fertilization lasted in average 96,81 days.

Bielfeldt et al. (2004) investigated the effect of systematic factors on fertility traits of Brown Swiss cows, and established highly significant effect of region on duration of service period and duration of interval between calving $(\mathrm{P}<0,01)$.

By analyzing certain paragenetic factors on fertility traits of bull dams of Simmental breed, Pantelic et al. (2005) established that the effect of region was highly significant $(\mathrm{P}<0,01)$ on age at first conception, duration of service period and interval between calving.

\section{Material and methods}

The effect of breeding region on variability of age at first calving and duration of service period in 3.461 first calving Simmental cows under control, reared on private farms on the territory of Republic of Serbia was established in this research. For the purpose of more precise determination of the effect of different paragenetic factors, all first calving cows included in this research were divided into 7 breeding regions according to the territory where the heads of cattle were reared: Valjevo)

1. Mačva-Kolubara region (territory of municipalities of Šabac and

2. Braničevo-Podunavlje region (territory of municipalities of Požarevac and Smederevo) Kragujevac)

3. Šumadija region (territory of municipalities of Mladenovac and Kruševac)

4. Raška-Rasina region (territory of municipalities of Kraljevo and 
5. Zlatibor-Morava region (territory of municipalities of Užice and Čačak)

6. Zaječar region (territory of municipality of Zaječar)

7. South region (territory of municipalities of Pirot, Leskovac, Prokuplje and Niš)

Because of the specific traits of the terrain, i.e. almost the same configuration, nutrition, and housing conditions and method, breeding regions were grouped, except region of Zaječar which is presented independently.

In the analysis of collected data the method of Least Squares was used LSMLMW (Harvey 1990). This method enables optimal consideration of numerous influences on investigated traits (in this case breeding region). Applied model used for evaluation of phenotypic variability of fertility traits and investigation of the effect of breeding region is presented in the following equation:

$$
\mathrm{Y}_{\mathrm{km}}=\mu+\mathrm{R}_{\mathrm{k}}+\mathrm{e}_{\mathrm{km}}
$$

$\mathrm{Y}_{\mathrm{km}} \quad=$ demonstration of fertility traits of $m$ cow producing in $k$ region

$$
\begin{array}{ll}
\mu & =\text { general average } \\
\mathrm{R}_{\mathrm{k}} & =\text { fixed effect of } k \text { region } \\
\mathrm{e}_{\mathrm{km}} & =\text { random error }
\end{array}
$$

\section{Results and discussion}

Deviation from the general average, mean values of least squares and significance of investigated effects on fertility traits are presented in tables 1 and 2.

Applying the method of Least Squares average service period of 115,19 days was established, also age at first calving of 795,53 days, in 3.461 first calving cows. Lower values of service period were established by Đurđević (2001), and slightly higher values by Petrović (2000). 
Table 1. General average $(\mu)$ and errors of general average (SE) for fertility traits in the first lactation of F-test investigated influences $(n=3461)$

Tabela 1. Opšti prosek $(\mu)$ i greške opšteg proseka (SE) za osobine plodnosti u prvoj laktaciji i F-test ispitivanih uticaja $(n=3461)$

\begin{tabular}{|c|c|c|c|}
\hline \multirow[b]{2}{*}{$\begin{array}{l}\text { Osobine/ } \\
\text { Traits }\end{array}$} & \multirow[b]{2}{*}{$\mu$} & \multirow[b]{2}{*}{ SE } & F - test \\
\hline & & & $\begin{array}{c}\text { Region } \\
d f_{1}=6 \\
d f_{2}=3351\end{array}$ \\
\hline $\begin{array}{l}\text { TSP, dana/ } \\
\text { DSP, days }\end{array}$ & 115.19 & 5.05 & $4.77 * *$ \\
\hline $\begin{array}{l}\text { UPT, dana } \\
\text { AFC, days }\end{array}$ & 795.53 & 10.04 & $11.24 * *$ \\
\hline
\end{tabular}

Service period, i.e. interval between calving and subsequent fertilization represents one of the most important fertility traits. It is considered that optimal duration of service period should be 90 days, since in this time the involution of genital organs in completed and they are ready for next fertilization, and, on the other hand, this is the best time from the economical aspect considering the natural progress of lactation in cows.

Heifers which are included in breeding to early lag behind in their growth and often remain small in their exterior as adult heads. Calving in such heads is regularly very difficult. Because of this, duration of service period is prolonged compared to normally formed and timely mated heifers. Considering genetic capacities of population, quantity of milk in such cases is considerably low during the first lactation.

Effects of breeding region can be major environment factors which influence the milk production. Knowledge of the effect of these systematic factors of the environment on milk production and fertility traits and their consideration in selection models is of special importance for accuracy of evaluation of genetic parameters and breeding value of bulls as well as cows as selection candidates. Numerous factors are considered as the effects of breeding region, they complement each other, however the most important is nutrition (Pantelić 2006). 
Table 2. Deviations of least squares ( $\hat{\mathbf{c}})$ and deviation errors (Ŝ́) for fertility traits in the first lactation according to regions

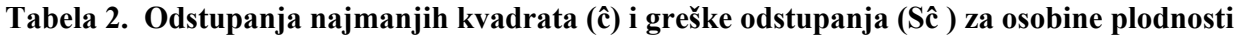
u prvoj laktaciji prema regionima

\begin{tabular}{|c|c|c|c|c|}
\hline $\begin{array}{c}\text { Osobine/ } \\
\text { Traits }\end{array}$ & $\mu$ & SE & \multicolumn{2}{|c|}{$\begin{array}{c}1 \\
(n=342)\end{array}$} \\
\hline $\begin{array}{l}\text { TSP, dana/ } \\
\text { DSP, days }\end{array}$ & 115.19 & 5.05 & -17.86 & 4.98 \\
\hline \multirow[t]{3}{*}{$\begin{array}{l}\text { UPT,dana/ } \\
\text { AFC, days }\end{array}$} & 795.53 & 10.04 & -19.99 & 7.83 \\
\hline & \multicolumn{2}{|c|}{$\begin{array}{c}2 \\
(n=689)\end{array}$} & \multicolumn{2}{|c|}{$\begin{array}{c}3 \\
(n=737)\end{array}$} \\
\hline & $\hat{\mathbf{c}}$ & Ŝ́ & $\hat{\mathbf{c}}$ & Ŝ́ \\
\hline $\begin{array}{l}\text { TSP, dana/ } \\
\text { DSP, days }\end{array}$ & 16.12 & 3.54 & -3.35 & 3.01 \\
\hline \multirow[t]{3}{*}{$\begin{array}{l}\text { UPT, dana/ } \\
\text { AFC, days } \\
\end{array}$} & 0.53 & 5.56 & 5.90 & 4.73 \\
\hline & \multicolumn{2}{|c|}{$\begin{array}{c}4 \\
(n=653)\end{array}$} & \multicolumn{2}{|c|}{$\begin{array}{c}5 \\
(n=219)\end{array}$} \\
\hline & $\hat{\mathbf{c}}$ & Ŝ́ & $\hat{\mathbf{c}}$ & Ŝे \\
\hline $\begin{array}{l}\text { TSP, dana/ } \\
\text { DSP, days }\end{array}$ & 4.27 & 3.13 & -9.83 & 5.75 \\
\hline \multirow[t]{3}{*}{$\begin{array}{l}\text { UPT, dana/ } \\
\text { AFC, days }\end{array}$} & 1.23 & 4.93 & 46.87 & 9.05 \\
\hline & \multicolumn{2}{|c|}{$\begin{array}{c}6 \\
(n=416)\end{array}$} & \multicolumn{2}{|c|}{$\begin{array}{c}7 \\
(n=405)\end{array}$} \\
\hline & $\hat{\mathbf{c}}$ & Ŝ́ & $\hat{\mathbf{c}}$ & Ŝ́ \\
\hline $\begin{array}{l}\text { TSP, dana/ } \\
\text { DSP, days }\end{array}$ & 11.62 & 5.07 & -0.97 & 3.69 \\
\hline $\begin{array}{l}\text { UPT, dana/ } \\
\text { AFC, days }\end{array}$ & 3.61 & 7.98 & -38.16 & 5.80 \\
\hline
\end{tabular}

Regions influenced highly significantly $(\mathrm{P}<0,01)$ age at first calving and duration of service period. The shortest service period was established in cows in Mačva-Kolubara region - 97,33 days, and the longest in BraničevoPodunavlje region - 131,31 days.

The greatest negative deviation of age at first calving from the general average was $-38,16$ days established in South region (average age - 757,36 
days), and the greatest positive deviation was 46,87 days established in cattle from Zlatibor-Morava region (average age - 842,40 days).

Highly significant effect of region on duration of service period was concluded in the research of Skalicki et al. (1991), Bielfeldt et al. (2004) and Pantelić et al. (2005), whereas Skalicki et al. (1991) established significant effect $(\mathrm{P}<0,05)$ on age at first fertilization and calving.

\section{Conclusion}

The effects of breeding region can be main environment factors influencing the milk production.

Knowledge of the effect of these systematic factors of the environment on milk production and fertility traits and their consideration in selection models is of special importance for accuracy of evaluation of genetic parameters and breeding value of bulls as well as cows as selection candidates.

Regions influenced highly significantly $(\mathrm{P}<0,01)$ age at first calving and duration of service period, and obtained results indicate that adjustment of the systematic effects of the environment is justified, for the purpose of more precise evaluation of breeding value of bulls.

One of the conclusions relating to this trait - age of heifers at first fertilization and calving is that it represents more technological characteristic since it depends on the nutrition level, need for herd replacement and breeding goal.

In case of significant problems in reproduction, beside consequences in production of milk and milk fat, also difficulties in normal realization of herd replacement occur, and this reflects certainly on economical efficiency of the production. 


\title{
Uticaj odgajivačkog područja na pojedine parametre plodnosti krava simentalske rase
}

\author{
V. Pantelić, Z. Skalicki, M. M. Petrović, S. Aleksić, D. Ostojić-Andrić, Ž. \\ Novaković
}

\section{Summary}

Oblast reprodukcije goveda je najznačajnija faza proizvodnje jer se u toj fazi obezbeđuju grla za remont stada, proizvodnju mleka i tov, odnosno proizvodnju mesa.

Regioni su visoko signifikantno uticali $(\mathrm{P}<0,01)$ na uzrast pri prvom telenju i na dužinu servis perioda, a dobijeni rezultati ukazuju na opravdanost korekcije sistematskih uticaja okoline, radi tačnije ocene oplemenjivačke vrednosti bikova. Primenom metoda najmanjih kvadrata ustanovljen je prosečan servis period od 115,19 dana i uzrast pri prvom telenju od 795,53 dana.

Ukoliko dođe do ozbiljnijih problema u reprodukciji, pored neposrednih posledica na proizvodnju mleka i mlečne masti nastaju i poteškoće u normalnoj realizaciji remonta stada, što se itekako odražava na ekonomičnost proizvodnje.

Ključne reči: simentalska rasa, plodnost, regioni.

\section{Literatura}

BIELFELDT, C.J., BADERTSCHER, R., TOLE, K.H. (2004): Influence of systematic effects on fertiliy traits in Swiss Brown cows. Archiv fur Tierzucht, Dummerstorf 47, 6, 537-549.

ĐURĐEVIĆ, R. (2001): Genetička analiza mlečnosti i reprodukcijskih svojstava krava simentalske rase. Doktorska disertacija. Poljoprivreni fakultet, Novi Sad. 
HARVEY W.R. (1990): Mixed model Least Squares and maximum Likelihood Computer Program. User, s Guiede for LSML MW and MIX MDL.

PANTELIĆ, V. (2006): Fenotipska i genotipska varijabilnost proizvodnih osobina prvotelki simentalske rase u različitim regionima Srbije. Doktorska disertacija. Poljoprivredni fakultet, Beograd.

PANTELIĆ, V., SKALICKI, Z., LATINOVIĆ, D., PETROVIĆ, M.M, KUČEVIĆ, D. (2005): Ispitivanje dejstva pojedinih paragenetskih faktora na osobine plodnosti bikovskih majki simentalske rase. Biotehnologija u stočarstvu, vol 21, (3-4), p. 35-41.

PETROVIĆ, D.M (2000): Ispitivanje dugovečnosti, proizvodnje mleka i mlečne masti krava simentalske rase. Magistarski rad. Poljoprivredni fakultet, Beograd. SKALICKI, Z., LATINOVIĆ, D., LAZAREVIĆ, LJ., STOJIĆ, P. (1991): Fenotipske karakteristike reproduktivnih osobina crno belih goveda sa različitom proporcijom gena holštajn-frizijske rase. Zbornik radova Poljoprivrednog fakulteta, Beograd.

TRIFUNOVIĆ, G., LATINOVIĆ, D., MEKIĆ, C., ĐEDOVIĆ RADICA, PERIŠIĆ, P., BUNEVSKI, G., NIKOLIĆ, R. (2004): Uticaj nivoa prinosa mleka na osobine plodnosti goveda. Biotehnologija u stočarstvu 20 (5-6), p. 3540 . 